\title{
"Effect of financial deepening on economic growth: Does it encourage income group transition?"
}

\begin{tabular}{|c|c|}
\hline AUTHORS & $\begin{array}{l}\text { Yuliia Shapoval (iD } \\
\text { R } \\
\text { Oleksii Shpanel-Yukhta (iD) }\end{array}$ \\
\hline ARTICLE INFO & $\begin{array}{l}\text { Yuliia Shapoval and Oleksii Shpanel-Yukhta (2021). Effect of financial } \\
\text { deepening on economic growth: Does it encourage income group transition?. } \\
\text { Banks and Bank Systems, 16(4), 101-113. doi:10.21511/bbs.16(4).2021.09 }\end{array}$ \\
\hline DOI & http://dx.doi.org/10.21511/bbs.16(4).2021.09 \\
\hline RELEASED ON & Monday, 22 November 2021 \\
\hline RECEIVED ON & Friday, 08 October 2021 \\
\hline ACCEPTED ON & Friday, 19 November 2021 \\
\hline LICENSE & $\begin{array}{l}(\mathrm{cc}) \overline{\mathrm{EY}} \\
\text { This work is licensed under a Creative Commons Attribution } 4.0 \text { International } \\
\text { License }\end{array}$ \\
\hline JOURNAL & "Banks and Bank Systems" \\
\hline ISSN PRINT & $1816-7403$ \\
\hline ISSN ONLINE & $1991-7074$ \\
\hline PUBLISHER & LLC "Consulting Publishing Company "Business Perspectives" \\
\hline FOUNDER & LLC "Consulting Publishing Company "Business Perspectives" \\
\hline
\end{tabular}

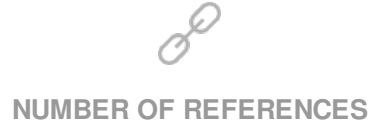

42

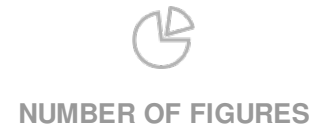

0
NUMBER OF TABLES

7

(C) The author(s) 2021. This publication is an open access article. 


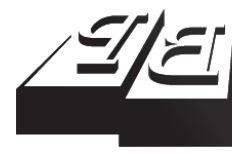

\section{BUSINESS PERSPECTIVES}

LLC "CPC "Business Perspectives" Hryhorii Skovoroda lane, 10, Sumy, 40022, Ukraine www.businessperspectives.org
Received on: $8^{\text {th }}$ of October, 2021 Accepted on: $19^{\text {th }}$ of November, 2021 Published on: 22 $2^{\text {nd }}$ of November, 2021

(C) Yuliia Shapoval, Oleksii ShpanelYukhta, 2021

Yuliia Shapoval, Ph.D. in Economics, Scientific Fellow, Department of Monetary Relations, Institute for Economics and Forecasting, National Academy of Sciences of Ukraine, Ukraine. (Corresponding author)

Oleksii Shpanel-Yukhta, Ph.D. in Economics, Junior Scientific Fellow, Department of Monetary Relations, Institute for Economics and Forecasting, National Academy of Sciences of Ukraine, Ukraine.
This is an Open Access article, distributed under the terms of the Creative Commons Attribution 4.0 International license, which permits unrestricted re-use, distribution, and reproduction in any medium, provided the original work is properly cited.

Conflict of interest statement: Author(s) reported no conflict of interest

Yuliia Shapoval (Ukraine), Oleksii Shpanel-Yukhta (Ukraine)

\title{
EFFECT OF FINANCIAL DEEPENING ON ECONOMIC GROWTH: DOES IT ENCOURAGE INCOME GROUP TRANSITION?
}

\begin{abstract}
The rapid growth of financial deepening raises the problem of its effect, beneficial for economic development. This paper aims to demonstrate the relationship between economic growth (GDP per capita growth, GNI per capita) and financial depth (domestic credit to private sector and credit availability) in 142 countries, split into four income groups, over 2000-2020, using correlation analysis and data from the World Bank and the IMF. Besides, a comparative analysis of domestic credit to the private sector, economic freedom, Gini index, total government expenditure and national savings of countries that increased their income group status over 2011-2020 is presented. Financial deepening (increased credit availability and expansion of domestic credit to the private sector) encourages economic growth (via GNI per capita and GDP per capita growth). Although the presence of a nonlinear relationship between economic growth (GDP per capita growth) and financial depth (domestic credit to private sector and credit availability) over 1991-2020 is insufficient, there is a linear relationship between GNI per capita and credit availability, between credit availability and domestic credit to the private sector for the same sample of countries over 2000-2020. Meanwhile, there is a tendency towards a decrease in the correlation between GNI per capita and GDP per capita growth. Given the revealed linear correlation between domestic credit to the private sector and GNI per capita, financial deepening positively impacts income growth, and this dependence strengthens with increasing income levels. Target values of domestic credit to the private sector are proposed for the income group transition.
\end{abstract}

Keywords

JEL Classification

\section{INTRODUCTION}

Although financial depth is traditionally associated with the development of the banking system and increasing the stock market's capitalization, financial deepening is subject to a number of significant downside risks. Recent economic slowdowns in large emerging countries, along with the problem of the "middle-income trap" bring up the issue of reaching a certain level of financial depth, which can be one of the tools for moving to the next income group. The experience of advanced economies demonstrates that on the shift to higher income groups, profits from accrued capital, technology transfer, and structural transformation decrease, as productivity and economic growth also do. Total factor productivity growth was stagnant or slowing in many advanced countries even before the financial crisis of 2008. It is not enough for medium-term economic growth just to increase factor accumulation even in advanced countries (Dabla-Norris et al., 2015, p. 5).

In the face of new normality, financial deepening is turning from factors of economic growth to aspects of economic destabilization. The advent of the COVID-19 pandemic has sharply affected key economic 
variables, raising questions about the ways of revitalizing long-term growth. The economic growth rates of advanced and developing countries continue to diverge. According to the International Monetary Fund economic projections, the growth prospects for a group of low-income developing countries have been significantly worsened (in particular, since the pandemic, 65 to 75 million additional people worldwide are estimated to be in extreme poverty) (Gopinath, 2021). The post-COVID-19 economy is also characterized by accelerated financialization. While financial development provides faster economic growth in some countries, in others, it is unproductive. There is a growing concern about the over-indebtedness of emerging economies. Globally, government debt stood at a five-decade record of 97\% of GDP and in emerging markets and developing economies at a three-decade record of 63\% of GDP in 2020 (Kose et al., 2021). At the end of January 2021, global broad money stood at USD 106.7 trn: growing at an annual rate of $+13.2 \%$, the highest rate posted since 1986 (during the great financial crisis, global money growth peaked at "only" $+10.5 \%$ ) (Barthalon, 2021). Under these circumstances, emerging economies can be oversaturated with money supply, which may be subject to inflationary processes. These realities call for a fundamental rethinking of how economies can benefit from the active development of the financial sector.

\section{LITERATURE REVIEW}

Given the financial deepening of the economy, the processes of financialization and monetization are often implicated. While financial deepening is the process of saturating the economy with financial resources, financialization of the economy is the process of outpacing the development of the financial sector compared to other sectors. At its broadest, the concept of financialization is the "increasing role of financial motives, financial markets, financial actors and financial institutions in the operation of economies" (Epstein, 2005, p. 3). Financialization is also considered "as a pattern of profits accumulation through financial channels rather than trade and commodity production" (Krippner, 2005, p. 174). Financialization is said to "elevate the significance of the financial sector relative to the real sector; transfer income from the real sector to the financial sector; and contribute to increased income inequality and wage stagnation" (Palley, 2013, p. 17). In line with Bortz and Kaltenbrunner (2017), financialization is more than just an increase in finance, as it is characterized by qualitative changes in the way economic agents integrate into international financial markets. Mader et al. (2020) stress that today researchers, despite different approaches to financialization, agree on an implicit search for pushback against the expansion of finance due to its unstable and harmful distributional consequences.

Financial deepening and financial development are also not identical concepts, as the latter is broader and covers both financial depth and financial inclusion. It should be noted that financial deepening means not just an increase of quantitative indicators or qualitative change of elements of the financial sector, but also the resulting feature of financial development, which demonstrates the saturation of the economy with financial resources. At the same time, financial depth is broader than the concept of monetization of the economy. However, the latter term is often used to reflect, at first glance, the same phenomenon, the increase of broad money to GDP ratio. Monetization as a process characterizes the degree of saturation of the economy with money, and is considered mainly in terms of money circulation.

The relationship between financial structure and economic development was pioneered by Goldsmith. Following him, Shaw focused on "financial repression due to unattractive yields on domestic financial assets, causing reduced saving rates and misallocation of investment, that adversely affect the growth rate" (Cole, 1974, p. 1346). In parallel, McKinnon noted that "a disciplined fiscal policy ends high inflationary expectations; high nominal rates of interest yield an increased willingness to hold assets in bank deposits, and the rise in the money stock exceed the rise in GNP" (Rostow, 1974, p. 1823). In contrast, Thornton (1994) argues that in many cases financial deepening does not make much difference to the economic growth in the short run.

Unlike McKinnon-Shaw's approach on assuming a more effective official banking system at allocat- 
ing funds, Beck's (2003) analysis of 40 developed and developing countries over the 1975-1998 period provides substantial justification for the importance of banks and stock markets.

Analyzing the effect of domestic debt accumulation in 93 low-income countries and emerging markets (over 1975-2004), Abbas and Christensen (2009) stress the overall positive impact of its moderate noninflationary level. Specifically, "above a ratio of $35 \%$ of bank deposits, domestic debt begins to undermine growth, lending credence to traditional crowding out and bank efficiency concerns" (Abbas \& Christensen, 2009, p. 209).

In view of "too much finance" theory, Panizza (2017) singles out financial crises, misallocation of talents, different types of finance, the structure of the financial system, political capture as the channels through which a very large financial sector can slow down economic growth. Before that, Panizza and colleagues (Arcand et al., 2015) have suggested that financial depth's marginal effect on economic growth becomes negative when credit to the private sector reaches $100 \%$ of GDP.

Concerning financial fragility and private credit, Demetriades et al. (2017) summarize that "a large volume of impaired loans has strengthened the negative effects of private credit on economic growth for 124 countries during 1998-2012, over and above the negative effects of systemic banking crises" (p. 16). But after quantitative easing, as stated by Perillo and Battiston (2020), the increase in loans and deposits, debt securities, shares and other capital is not associated with more enforcement of real economy financing.

More recently, the existence of bi-directional causality between financial development indices and the real GDP growth is stressed in Ferreira's (2021) exploration of 46 countries over 1990-2017. Ganguly (2021) identifies that as periods of the greater extent of financialization are typically associated with lower profitability across non-financial firms in India, the conduit of financialization of the real economy in developing countries is the slowdown in their industrial sector. At the same time, Bui and Doan (2021) highlight the positive impact of the stock market development on economic growth among developing economies in Asia over 2008-2019.
Financial deepening may also, directly and indirectly, affect income inequality. While the debate on the link between economic development and inequality started since Kuznets (1955), Greenwood and Jovanovic (1990) were among the first researchers to examine the finance-inequality nexus. They outline that the economy with a developed financial structure achieves a stable distribution of the population's income and higher economic growth rate. As soon as the level of income rises, the financial structure becomes more extensive, economic growth accelerates. By the way, according to the Kuznets curve (1955), during the first phase of economic growth, income inequality increases, reaches a peak and then decreases to an acceptable level in a later phase after reaching a certain level of income. In a subsequent study, Greenwood et al. (2013) provide evidence of the importance of technological improvement in financial intermediation for economic development.

Similar arguments are used in Clarke et al. (2003). They summarized that the growth-promoting effects of financial intermediaries cause a positive impact on total income distribution and a dampening impact on income inequality depending upon the economic structure of the economy. In line with previous conclusions, Honohan (2004), investigating the effect of finance on sustainable economic development, claims that financially intensive growth (namely banking depth) leads to lower poverty rates. In turn, Claessens and Perotti (2007) identify that the links between financial development and inequality are the result of the "influence of the political and economic elites exercise over a country's institutional environment" (p. 766).

Brei et al. (2018) suggest the non-linear, not monotonic, link between financial development and income inequality accounting for financial structure in 97 advanced and emerging countries. In contrast to the predictions of Greenwood and Jovanovic (1990), Brei et al. (2018) ground "beneficial a U-shaped relationship between financial development and inequality, and stress that more financial development is associated with reductions in income inequality below a certain threshold, beyond which further financial development correlates with higher income inequality" (p. 18). 
Regarding the relationship of financial deepening and income inequality in the Chinese economy, Kotarski (2015) reveals the significant correlation between monetary aggregate M2/GDP and domestic banking credit/GDP ratios with rising income inequality. De Vita and Luo (2020) substantiate that household indebtedness (among financial, nonfinancial and household sectors of financialization) affects income inequality across 33 countries over 1996-2015. Recent work by Chu and Jiang (2021), using China's data, reveals that "financial depth explains 11-28\% of the overall variations of urban income inequality during 19812016” (p. 229). In contrast, De Haan et al. (2021) declare that, during 1975-2014 in 84 countries, financial development does not directly reduce the poverty gap and indirectly increases poverty, causing more income inequality.

Ukrainian researchers have also debated much about the relationship between economic growth and financialization in the context of the domestic economy (Anufriieva et al., 2021). In particular, Kozmenko and Korneyev (2017) define the negative effect of imbalances in the movement of financial resources caused by financialization (M3, the volume of loans to the private sector, assets of the financial sector to gross domestic product) on the economic growth of Ukraine. Characterizing the positive impact of employment, exports of goods and services, added value created in the industrial sector, the ratio of bank capital and reserves to total assets, M1 to GDP ratio, deposit rate, and Gini index on the economic growth of Ukraine, Moldova and Georgia, Shkolnyk et al. (2019) single out the ratio of the bank's capital and reserves to total assets, M1 to GDP ratio and Gini index as the most statistically significant indicators of financialization throughout 2007-2017. Rushchyshyn et al. (2021) discover a strong favorable relationship between the level of the banking sector development and GDP per capita and a reverse relationship with the level of national poverty in Ukraine during 2000-2019.

As financialization can lead to excessive consumption and debt growth, Buryk et al. (2019) conclude that a positive impact of public debt on economic development is possible only under "advanced pace of economic growth, in a high level of demand for loan capital and by an annual GDP growth rate of more than $3 \%$, in which case the government debt does not exceed the 60\% of GDP" (p. 178). Similarly, Bogdan and Lomakovych (2021) highlight the issue of a low level of financial deepening with a simultaneous high volume of external debt, which indicates a distortion of credit funds towards external financing.

Financial deepening can also cause inflationary processes in case of oversaturation of the economy. Although higher monetization is generally associated with a positive effect of the banking system on economic growth, an increase in the money supply can provoke an inflation leap. Particularly, Shvets (2021) reveals economies fragile to the aggressive money expansion that opposes the achievement of a short-run ready balance between the real value of money supply and output under the terms of unflexible prices in a short time. The author asserts that aggressive monetary expansion, which contributes to the recovery of the national economy, is the result of the large money market of the national currency circulation.

Overall, the academic affiliation between the growth of banking sector and stock market, and economic development is quite widely verified empirically. The financial development across different economies over various time horizons has a causal and positive effect on long-term growth due to increased overall factor productivity. Financial markets are becoming the cause of financial destabilization through debt accumulation and a high rate of monetization. In recent years, policy and academic communities have expressed growing concern about the negative correlation between financial depth and economic growth when domestic credit to the private sector is close to $100 \%$ of GDP.

Therefore, research on the finance-growth nexus leaves a number of questions open concerning its threshold, after which the beneficial effect of financial deepening is diminishing. The significance of the current study is that it investigates the effect of financial deepening on economic growth in the context of changing income groups status, as the level of financial depth can explain cross-country variation, particularly in economic development.

The foregoing suggests a hypothesis: Financial deepening (an increase in the credit availability indicator leads to expansion of domestic credit 
to private sector) as a cumulative financial source positively changes the economic growth pattern (via GNI per capita and GDP per capita growth), contributing to the economy's capacity to finance the transition from low-income to middle- or high-income status.

\section{AIMS}

To examine the effect of financial deepening on economic growth, on the one hand, the relationship between GDP per capita growth, GNI per capita and, on the other hand, domestic credit to private sector and credit availability, with respect to income group transition, is under consideration.

\section{METHODS}

Method of comparison of correlations in diagonals is employed in this study to characterize the relationship between economic growth (GDP per capita growth, GNI per capita) and financial depth (domestic credit to the private sector as \% GDP and credit availability), using World Bank's and IMF's databases. Internal links between individual groups of indicators are assessed by the pairwise correlation coefficient and checking the reliability of the respective coefficients according to the Student's $\mathrm{t}$-test. The set of 142 countries for correlation matrix analysis is determined by the maximum number of countries for which data for comparison is available. Given that financial deepening is a factor in income groups transition, economies are considered via four income groupings. The chosen country income grouping method allows contrasting the dependence between analyzed variables with the economic development phase.

The effect of financial depth on economic growth is verified using the following indicators:

- GDP_PC_gr - GDP per capita growth (annual, \%);

- GNI_PC_atl - GNI per capita (Atlas, current, US dollar);

- DC_GDPpct - domestic credit to private sector (\% of GDP);
- DC_GDPpct_diff - difference of DC_GDPpct between previous and current year;

- GNI_PC_atl_diff-difference of GNI_PC_atl between previous and current year.

The values from the sample for which the corresponding data is absent or not measured during the study period is excluded for the clarity of data obtained. The adjusted credit availability indicator of the banking sector, which is based on broad money and monetary base indicators measured in the domestic currency according to IMF methodology (IMF, 2021), is assessed as follows:

$$
\text { Credit availability }=1-\frac{M B}{B M},
$$

where $M B$ is the monetary base, and $B M$ is the broad money.

Hence, credit availability is the adjusted broad money ratio by excluding the cash in circulation and required reserves (i.e. money that could not be converted into credit resources).

Further, correlation matrix analysis is complemented by comparative analysis of domestic credit to the private sector (\% of GDP; annual change, percentage points), economic freedom (index of economic freedom, \%), Gini index, total government expenditure (\% of GDP) and gross national savings (\% of GDP) of countries that have increased their income group status over 2011-2020. Herewith, only those economies that have not reversed to the previous income group are used to obtain a more accurate result.

Comparative and correlation analyses are carried out using values in the periods $t, t-1$ and $t-2$ according to the transition year.

\section{RESULTS}

The correlation analysis covers 44 high-income, 42 upper-middle-income, 38 lower-middle-income, 18 low-income countries over 2000-2020. The descriptive data on the variables employed in analyzing the whole sample is presented in Table 1. 
Table 1. Descriptive statistics, 2000-2020

Source: Compiled by the authors based on the World Bank and IMF data (2021).

\begin{tabular}{|c|c|c|c|c|c|c|}
\hline Variable & Income level & Minimum & Maximum & Average & Median & Std. deviation \\
\hline$G D P_{-} P C_{-} g r$ & High-income & -14.46 & 24.00 & 1.35 & 1.52 & 3.40 \\
\hline$G D P \_P C \_g r$ & Upper-middle-income & -12.98 & 32.17 & 2.23 & 2.46 & 3.75 \\
\hline$G D P \_P C_{-} g r$ & Lower-middle-income & -9.44 & 18.85 & 2.87 & 2.99 & 3.28 \\
\hline$G D P_{-} P C_{-} g r$ & Low-income & -22.31 & 28.68 & 1.92 & 2.01 & 4.27 \\
\hline$G D P \_P C \_g r$ & All countries & -22.31 & 32.17 & 2.08 & 2.11 & 3.64 \\
\hline GNI_PC_atI & High-income & $4,130.00$ & $104,370.00$ & $33,584.16$ & $30,105.00$ & $19,621.42$ \\
\hline GNI_PC_atl & Upper-middle-income & $1,030.00$ & $15,190.00$ & $6,602.62$ & $6,185.00$ & $2,653.57$ \\
\hline GNI_PC_atl & Lower-middle-income & 210.00 & $5,510.00$ & $2,119.76$ & $1,800.00$ & $1,159.87$ \\
\hline GNI_PC_atl & Low-income & 120.00 & $1,540.00$ & 604.74 & 570.00 & 254.47 \\
\hline GNI_PC_atl & All countries & 120.00 & $104,370.00$ & $13,373.14$ & $5,480.00$ & $18,052.28$ \\
\hline GNI_PC_atI_diff & High-income & -19.10 & 36.52 & 4.33 & 3.36 & 8.24 \\
\hline GNI_PC_atl_diff & Upper-middle-income & -23.78 & 126.16 & 6.58 & 5.15 & 12.30 \\
\hline GNI_PC_atl_diff & Lower-middle-income & -25.56 & 45.57 & 6.55 & 5.70 & 8.67 \\
\hline GNI_PC_atl_diff & Low-income & -21.43 & 61.90 & 5.46 & 5.20 & 9.22 \\
\hline GNI_PC_atl_diff & All countries & -25.56 & 126.16 & 5.70 & 4.77 & 9.84 \\
\hline CreditAvailability & High-income & 0.32 & 0.98 & 0.82 & 0.83 & 0.11 \\
\hline CreditAvailability & Upper-middle-income & 0.01 & 0.96 & 0.71 & 0.73 & 0.17 \\
\hline CreditAvailability & Lower-middle-income & 0.12 & 0.93 & 0.67 & 0.69 & 0.15 \\
\hline CreditAvailability & Low-income & 0.19 & 0.81 & 0.58 & 0.62 & 0.16 \\
\hline CreditAvailability & All countries & 0.01 & 0.98 & 0.72 & 0.75 & 0.16 \\
\hline$D C \_G D P p c t$ & High-income & 20.07 & 304.58 & 89.31 & 80.12 & 48.48 \\
\hline$D C_{-}$GDPpct & Upper-middle-income & 2.15 & 160.12 & 49.07 & 41.38 & 31.55 \\
\hline$D C \_$GDPpct & Lower-middle-income & 3.12 & 114.19 & 35.45 & 30.64 & 21.22 \\
\hline$D C \_G D P p c t$ & Low-income & 1.10 & 40.16 & 13.11 & 11.70 & 7.55 \\
\hline$D C \_G D P p c t$ & All countries & 1.10 & 304.58 & 53.94 & 42.81 & 43.37 \\
\hline
\end{tabular}

A correlation analysis between economic growth (GDP per capita growth) and changes in the financial depth (domestic credit to private sector as \% GDP and credit availability) across 142 countries over 1991-2020 demonstrates the lack of a linear link. However, there is an indirect link across GNI per capita and credit availability based on correlation analysis for the same sample of countries over 2000-2020 (Table 2). In terms of revealed credit availability impact on the level of GNI per capita, the effect of financial depth is significantly lower (0.44-0.46) over 2000-2020 (Table 2). In comparison, the found effect of domestic credit to the private sector (as \% GDP) on GDP per capita growth is higher $(0.65-0.66)$.

There is a positive linear link between financial depth (domestic credit to private sector, \% GDP) and GNI per capita across all income groups over 2000-2020. This relationship is significant for high- and lower-middle-income countries, minor for upper-middle-income countries, and absent for low-income countries. Specifically, the level of correlation is 0.65 and, depending on income groups, ranges from 0.08 for low-income countries to 0.45 in high-income countries (Tables 3-6). The financial deepening (domestic credit to private sector as \% GDP) by $1 \%$ can increase GNI per capita by 269 US dollars.

There is a positive linear link between the level of private-sector lending (domestic credit to private sector, as \% of GDP) and credit availability of the banking sector across all income groups over 2000-2020. The correlation level between domestic credit to private sector (\% of GDP) and credit availability on t period is 0.52 - for low-income, 0.38 - for lower-middle income, 0.57 - for upper-middle income, and 0.37 - for high-income (Tables 3-6). Notably, the correlation coefficient between credit availability and difference of domestic credit to the private sector (as \% of GDP) between previous and current year (DC_GDPpct) is low (0.32-0.39) across high-income countries for periods $t, t-1, t-2$. This is due to the fact that these countries are characterized by a higher level of financial markets and access to financial services and products. 
Table 2. Correlation matrix between economic growth and financial depth, all countries, 2000-2020

\begin{tabular}{|c|c|c|c|c|c|c|c|c|c|c|c|}
\hline All countries & ธั' & 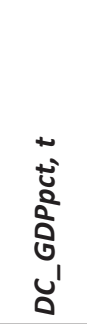 & 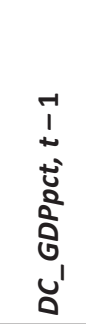 & 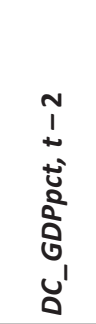 & 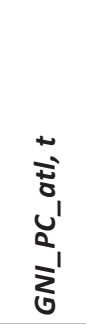 & 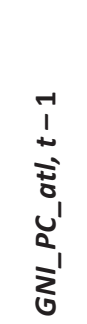 & 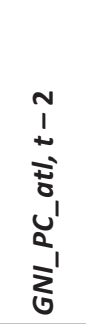 & 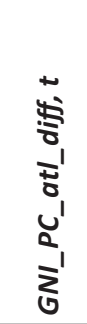 & 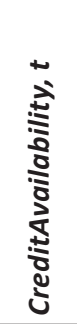 & 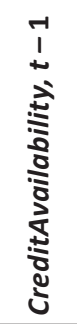 & 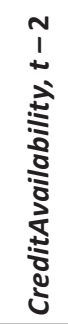 \\
\hline$G D P_{-} P C_{-} g r, t$ & 1.00 & - & - & - & - & - & - & - & - & - & - \\
\hline$D C_{-}$GDPpct, $t$ & -0.15 & 1.00 & - & - & - & - & - & - & - & - & - \\
\hline$D C_{-}$GDPpct, $t-1$ & -0.15 & 0.99 & 1.00 & - & - & - & - & - & - & - & - \\
\hline$D C \_$GDPpct, $t-2$ & -0.15 & 0.97 & 0.99 & 1.00 & - & - & - & - & - & - & - \\
\hline GNI_PC_atl, $t$ & -0.17 & 0.65 & 0.65 & 0.64 & 1.00 & - & - & - & - & - & - \\
\hline GNI_PC_atl, $t-1$ & -0.19 & 0.65 & 0.65 & 0.65 & 1.00 & 1.00 & - & - & - & - & - \\
\hline GNI_PC_atl, $t-2$ & -0.20 & 0.65 & 0.65 & 0.65 & 0.99 & 0.99 & 1.00 & - & - & - & - \\
\hline GNI_PC_atl_diff, $t$ & 0.53 & -0.17 & -0.18 & -0.19 & -0.12 & -0.17 & -0.20 & 1.00 & - & - & - \\
\hline CreditAvailability, $t$ & -0.09 & 0.56 & 0.55 & 0.54 & 0.44 & 0.44 & 0.43 & -0.11 & 1.00 & - & - \\
\hline CreditAvailability, $t-1$ & -0.08 & 0.57 & 0.56 & 0.56 & 0.46 & 0.45 & 0.44 & -0.11 & 0.97 & 1.00 & - \\
\hline CreditAvailability, $t-2$ & -0.09 & 0.57 & 0.57 & 0.57 & 0.47 & 0.46 & 0.46 & -0.10 & 0.93 & 0.96 & 1.00 \\
\hline
\end{tabular}

There is a steady decreasing tendency of the correlation between GNI per capita and GDP per capita growth across all countries during 2000-2020. For low-income countries, the corresponding correlation coefficient is 0.58 , while for high-income countries - 0.49 (Tables 3-6). As GNI per capita is by its nature a "purified" indicator of GDP per capita growth, its increase illustrates the growth of possibilities of income usage by households. The study detects only a short-term relationship between GNI per capita and GDP per capita growth. The growth of one of the mentioned indicators in the previous period does not lead to their growth in the next period. There is no similar dependence for the period $t-2$. Thus, accumulation of a certain level of income usage is vital for economic growth in the relevant accumulation period and by link with financial depth.

Table 3. Correlation matrix between economic growth and financial depth, high-income countries, 2000-2020

Source: Compiled by the authors based on the World Bank and IMF data (2021).

\begin{tabular}{|c|c|c|c|c|c|c|c|c|c|c|c|}
\hline High-income & ธ్ & 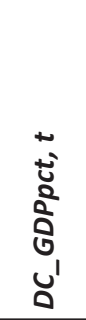 & 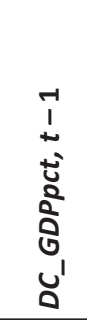 & 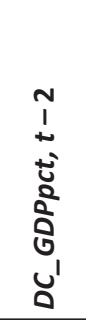 & 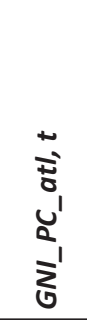 & 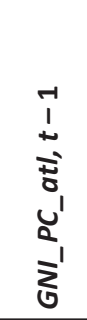 & 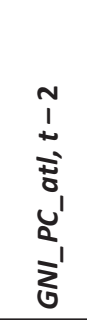 & 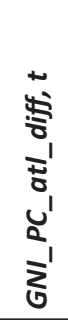 & 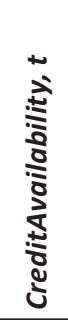 & 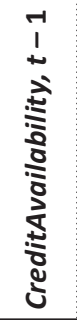 & 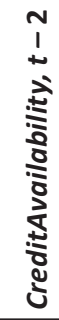 \\
\hline$G D P \_P C_{-} g r, t$ & 1.00 & - & - & - & - & - & - & - & - & - & - \\
\hline$D C_{-}$GDPpct, $t$ & -0.20 & 1.00 & - & - & - & - & - & - & - & - & - \\
\hline$D C_{-} G D P p c t, t-1$ & -0.17 & 0.98 & 1.00 & - & - & - & - & - & - & - & - \\
\hline$D C \_G D P p c t, t-2$ & -0.15 & 0.95 & 0.98 & 1.00 & - & - & - & - & - & - & - \\
\hline$G N I \_P C \_a t l, t$ & -0.16 & 0.45 & 0.43 & 0.42 & 1.00 & - & - & - & - & - & - \\
\hline$G N I \_P C \_a t l, t-1$ & -0.21 & 0.46 & 0.45 & 0.43 & 0.99 & 1.00 & - & - & - & - & - \\
\hline GNI_PC_atl, $t-2$ & -0.22 & 0.46 & 0.46 & 0.45 & 0.96 & 0.99 & 1.00 & - & - & - & - \\
\hline GNI_PC_atI_diff, $t$ & 0.49 & -0.19 & -0.21 & -0.22 & -0.12 & -0.24 & -0.31 & 1.00 & - & - & - \\
\hline CreditAvailability, $t$ & -0.12 & 0.37 & 0.35 & 0.32 & 0.40 & 0.38 & 0.35 & 0.09 & 1.00 & - & - \\
\hline CreditAvailability, $t-1$ & -0.11 & 0.39 & 0.37 & 0.34 & 0.41 & 0.39 & 0.37 & 0.07 & 0.92 & 1.00 & - \\
\hline CreditAvailability, $t-2$ & -0.11 & 0.41 & 0.39 & 0.37 & 0.43 & 0.42 & 0.39 & 0.04 & 0.84 & 0.91 & 1.00 \\
\hline
\end{tabular}


Table 4. Correlation matrix between economic growth and financial depth, upper-middle-income countries, 2000-2020

Source: Compiled by the authors based on the World Bank and IMF data (2021).

\begin{tabular}{|c|c|c|c|c|c|c|c|c|c|c|c|}
\hline Upper-middle-income & 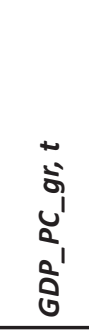 & 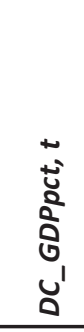 & 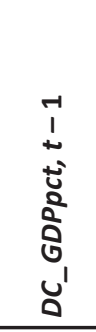 & 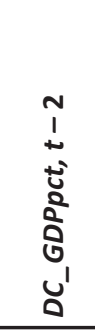 & 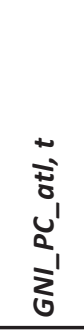 & 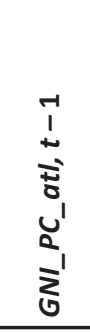 & 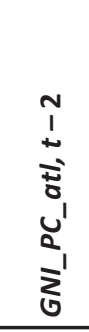 & 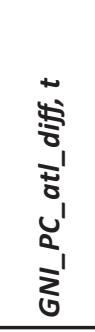 & 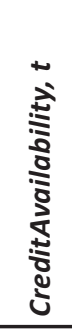 & 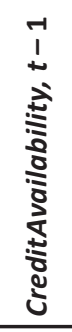 & 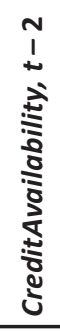 \\
\hline$G D P_{-} P C_{-} g r_{,} t$ & 1.00 & - & - & - & - & - & - & - & - & - & - \\
\hline$D C \_G D P p c t, t$ & -0.01 & 1.00 & - & - & - & - & - & - & - & - & - \\
\hline$D C_{-} G D P p c t, t-1$ & -0.01 & 0.99 & 1.00 & - & - & - & - & - & - & - & - \\
\hline$D C_{-} G D P p c t, t-2$ & -0.02 & 0.98 & 0.99 & 1.00 & - & - & - & - & - & - & - \\
\hline GNI_PC_atI, $t$ & -0.10 & 0.18 & 0.18 & 0.18 & 1.00 & - & - & - & - & - & - \\
\hline$G N I \_P C \_a t I, t-1$ & -0.22 & 0.19 & 0.19 & 0.19 & 0.97 & 1.00 & - & - & - & - & - \\
\hline$G N I \_P C_{-} a t l, t-2$ & -0.26 & 0.18 & 0.20 & 0.20 & 0.91 & 0.97 & 1.00 & - & - & - & - \\
\hline GNI_PC_atI_diff, $t$ & 0.52 & -0.16 & -0.17 & -0.17 & -0.19 & -0.38 & -0.47 & 1.00 & - & - & - \\
\hline CreditAvailability, $t$ & -0.04 & 0.57 & 0.57 & 0.56 & 0.13 & 0.14 & 0.15 & -0.21 & 1.00 & - & - \\
\hline CreditAvailability, $t-1$ & -0.02 & 0.56 & 0.56 & 0.56 & 0.11 & 0.12 & 0.13 & -0.18 & 0.96 & 1.00 & - \\
\hline CreditAvailability, $t-2$ & 0.01 & 0.55 & 0.56 & 0.56 & 0.11 & 0.11 & 0.12 & -0.13 & 0.93 & 0.96 & 1.00 \\
\hline
\end{tabular}

Table 5. Correlation matrix between economic growth and financial depth, lower-middle-income countries, 2000-2020

Source: Compiled by the authors based on the World Bank and IMF data (2021).

\begin{tabular}{|c|c|c|c|c|c|c|c|c|c|c|c|}
\hline Lower-middle-income & 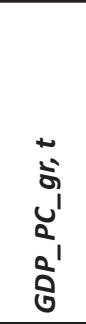 & 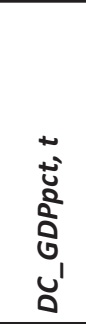 & 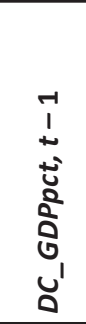 & 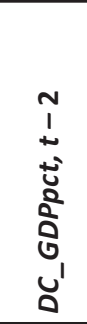 & 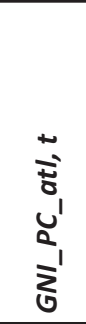 & 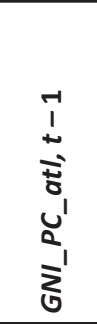 & 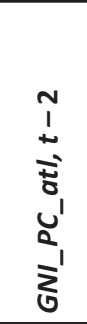 & 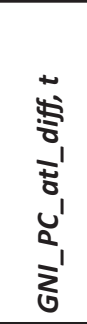 & 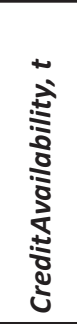 & 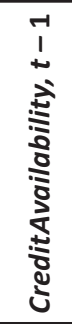 & 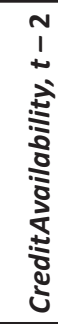 \\
\hline$G D P_{-} P C_{-} g r, t$ & 1.00 & - & - & & & - & - & - & - & - & - \\
\hline$D C \_G D P p c t, t$ & -0.10 & 1.00 & - & - & - & - & - & - & - & - & - \\
\hline$D C \_G D P p c t, t-1$ & -0.13 & 0.99 & 1.00 & - & - & - & - & - & - & - & - \\
\hline$D C \_G D P p c t, t-2$ & -0.15 & 0.96 & 0.99 & 1.00 & - & - & - & - & - & - & - \\
\hline GNI_PC_atl, $t$ & -0.22 & 0.51 & 0.52 & 0.53 & 1.00 & - & - & - & - & - & - \\
\hline$G N I \_P C \_a t l, t-1$ & -0.29 & 0.51 & 0.53 & 0.54 & 0.99 & 1.00 & - & - & - & - & - \\
\hline$G N I \_P C \_a t l, t-2$ & -0.31 & 0.51 & 0.53 & 0.54 & 0.97 & 0.99 & 1.00 & - & - & - & - \\
\hline GNI_PC_atl_diff, $t$ & 0.58 & -0.19 & -0.22 & -0.22 & -0.29 & -0.40 & -0.46 & 1.00 & - & - & - \\
\hline CreditAvailability, $t$ & -0.07 & 0.38 & 0.39 & 0.38 & 0.34 & 0.33 & 0.31 & -0.03 & 1.00 & - & - \\
\hline CreditAvailability, $t-1$ & -0.09 & 0.39 & 0.40 & 0.40 & 0.36 & 0.34 & 0.33 & -0.05 & 0.97 & 1.00 & - \\
\hline CreditAvailability, $t-2$ & -0.11 & 0.39 & 0.41 & 0.41 & 0.38 & 0.36 & 0.34 & -0.06 & 0.92 & 0.96 & 1.00 \\
\hline
\end{tabular}

The effect of financial deepening on economic growth is also analyzed by income group comparison. Relevance to a higher income group for a country reflects increasing investment attractiveness, solid resilience of the economy to external vulnerabilities and an increase in the country's positions in international rankings. Over 2011-
2020, 39 income group transition statuses were observed (9 of them shifting to the high-income group, 17 to the upper-middle-income group, 13 to the lower-middle-income group, Table 7). During the last three years before transition to the next income group, countries significantly reached the financial depth degree of the poten- 
Table 6. Correlation matrix between economic growth and financial depth, low-income countries, 2000-2020

Source: Compiled by the authors based on the World Bank and IMF data (2021).

\begin{tabular}{|c|c|c|c|c|c|c|c|c|c|c|c|}
\hline Low-income & 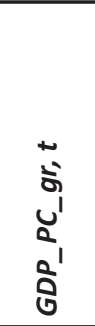 & 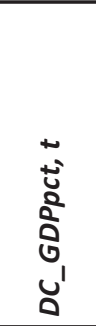 & 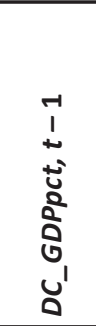 & 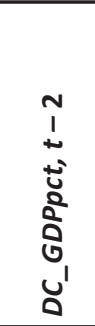 & 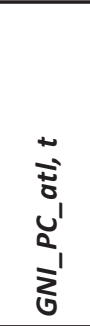 & 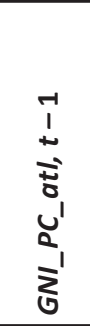 & 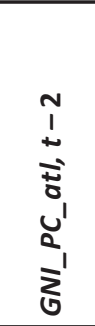 & 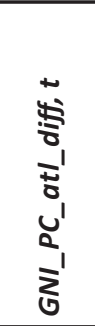 & 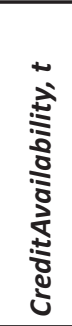 & 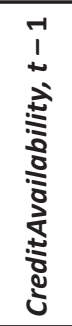 & 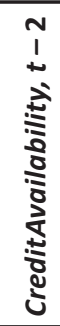 \\
\hline$G D P_{-} P C_{-} g r, t$ & 1.00 & - & - & - & - & - & - & - & - & - & - \\
\hline DC_GDPpct, $t$ & 0.01 & 1.00 & - & - & - & - & - & - & - & - & - \\
\hline$D C \_G D P p c t, t-1$ & 0.02 & 0.97 & 1.00 & - & - & - & - & & - & - & - \\
\hline$D C \_G D P p c t, t-2$ & 0.01 & 0.93 & 0.96 & 1.00 & - & - & - & - & - & - & - \\
\hline$G N I \_P C \_a t I, t$ & 0.08 & 0.08 & 0.09 & 0.09 & 1.00 & - & - & - & - & - & - \\
\hline$G N I \_P C \_a t l, t-1$ & -0.03 & 0.10 & 0.10 & 0.10 & 0.98 & 1.00 & - & - & - & - & - \\
\hline$G N I P P C a t l, t-2$ & -0.06 & 0.12 & 0.13 & 0.13 & 0.93 & 0.98 & 1.00 & - & - & - & - \\
\hline GNI_PC_atI_diff, $t$ & 0.58 & -0.20 & -0.19 & -0.18 & -0.19 & -0.38 & -0.46 & 1.00 & - & - & - \\
\hline CreditAvailability, $t$ & 0.10 & 0.52 & 0.52 & 0.51 & -0.20 & -0.19 & -0.16 & -0.08 & 1.00 & - & - \\
\hline CreditAvailability, $t-1$ & 0.10 & 0.53 & 0.54 & 0.53 & -0.16 & -0.15 & -0.12 & -0.10 & 0.97 & 1.00 & - \\
\hline CreditAvailability, $t-2$ & 0.06 & 0.52 & 0.54 & 0.54 & -0.15 & -0.14 & -0.10 & -0.12 & 0.93 & 0.96 & 1.00 \\
\hline
\end{tabular}

tial income group and exceeded the average level of financial depth across their current income group. Hence, there is a need for an accumulated financial depth (which makes it possible to ensure the economic circulation of credit resources) under the terms of a relationship between financial depth (domestic credit to private sector, \% of GDP; annual change in domestic credit to GDP, percentage points) and GDP growth (GDP annual growth, \%). As a higher level of financial depth is a prerequisite to transit to a higher group, the target values of domestic credit to private sector are proposed: for transition to lower-middle-income $-35.5 \%$, for transition to upper-middle-income -49.07 , for transition to the high-income group -89.31 .

Table 7. Change in economic indicators before the transition to the next income group status, average by group level, 2011-2020, \%

Source: Compiled by the authors based on the World Bank and Index of Economic Freedom data (2021).

\begin{tabular}{|c|c|c|c|}
\hline New Group, $t$ & High-income & Upper-middle-income & Lower-middle-income \\
\hline Old group, $t-1, t-2$ & Upper-middle-income & Lower-middle-income & Low-income \\
\hline Economic freedom, $t$ & 72.07 & 58.11 & 54.41 \\
\hline Economic freedom, $t-1$ & 71.27 & 58.30 & 54.26 \\
\hline Economic freedom, $t-2$ & 71.33 & 59.11 & 53.58 \\
\hline Domestic credit, $t$ & 64.19 & 55.59 & 30.08 \\
\hline Domestic credit, $t-1$ & 62.09 & 54.44 & 30.00 \\
\hline Domestic credit, $t-2$ & 62.88 & 53.37 & 28.49 \\
\hline Domestic credit, $\mathrm{t}$ & 0.01 & 0.02 & 0.01 \\
\hline Domestic credit Increase, $t-1$ & -0.02 & 0.03 & 0.03 \\
\hline Domestic credit Increase, $t-2$ & -0.05 & 0.06 & 0.06 \\
\hline Gini, $t$ & 42.70 & 41.56 & 39.00 \\
\hline Gini, $t-1$ & 41.63 & 39.49 & 42.20 \\
\hline Gini, $t-2$ & 41.38 & 39.10 & 35.85 \\
\hline Government total expenditure, $t$ & 28.54 & 32.26 & 25.34 \\
\hline Government total expenditure, $t-1$ & 28.74 & 31.62 & 25.92 \\
\hline Government total expenditure, $t-2$ & 29.38 & 33.27 & 25.88 \\
\hline National savings, $t$ & 21.81 & 22.06 & 23.23 \\
\hline National savings, $t-1$ & 21.57 & 22.78 & 22.69 \\
\hline National savings, $t-2$ & 21.84 & 23.29 & 23.63 \\
\hline
\end{tabular}


Another issue is access to sufficient financial resources and services in terms of instantly assessing financial inclusion and under index of economic freedom. Notably, a consonant gradation is observed: countries shifting to a high-income group on average have a level of economic freedom at $72 \%$, to the upper-middle-income group - 58\% and upper-middle-income group - 54\% (Table 7).

As generally accepted, the average income level rise at a sustainable level of the economic development leads to decreased income inequality (partly due to increasing degree of "guaranteed income" - pensions, social benefits, social insurance, etc.). World practice shows no significant decline in the Gini index across income groups (Table 7). The level of total government expenditure (\% of GDP) during GDP growth can, by default, increases due to the growth of taxes (that is, a GDP's function). At the same time, the comparative stability of government expenditure results in balancing government spending for countries moving to the following income group status. As a source of national investment, the level of gross national savings (\% of GDP) acts as a stimulator of economic growth at the macroeconomic level. Meanwhile, this study confirms that the transition to the next income group is not just guided by increasing the share of national savings in GDP.

\section{DISCUSSION}

The revealed positive linear link between credit availability of the banking sector and domestic credit to the private sector and simultaneous their positive effects on GNI per capita over 2000-2020 confirms the importance of financial deepening in improving credit capacity, which will boost economic growth. These results validate the existing literature that financial deepening has a statistically significant positive effect on economic growth (Beck, 2003).
Before the transition, countries reach the level of financial depth of the next income group, exceeding the average level of financial depth in their current income group. The income group transition positively influences the feasibility of engaging further external financing, decreasing the cost of external debt maintenance, promoting economic development and potential growth rates. Hence, financial depth can be regarded as a cumulative financial source for changing economic growth patterns via strengthening and improving the quality of financial sector structure, consequently, the economy's capacity to finance the transition from lower to higher-income status group. This conclusion about a positive relationship between financial development and income inequality is also confirmed by Clarke et al. (2003), Honohan (2004), and Brei et al. (2018).

At the same time, the correlation matrices indicate that the relationship between financial depth and economic growth is less significant for high-income countries. It implies that as the level of the economy grows and it moves to the next income group, the role of financial depth in economic growth decreases. It supports the findings of previous studies that after reaching a certain threshold, there is a negative relationship between financial depth and economic growth (Panizza, 2017; Arcand et al., 2015). This result is consistent with Demetriades et al. (2017), who find that credit growth is a predictor of financial crises.

The fact that financial deepening provides faster economic growth in some income groups while in others is unproductive, indicates the need to find ways to achieve a reasonable rate of economic deepening. The perspective of such research will address the challenges of the extent to which financial deepening can generate additional net resource flows into the real economy to sustain future economic growth.

\section{CONCLUSION}

This paper assesses the effect of financial deepening on economic growth by exploring whether financial deepening encourages income group transition. The results show that financial deepening (increase of credit availability that leads to a rise in domestic credit to the private sector) encourages economic growth (via GNI per capita and GDP per capita growth) both at the country level and at the level of income groups. Over 2000-2020, across four income groups, positive linear links are found between 
domestic credit to the private sector and credit availability of the banking sector, domestic credit to the private sector and GNI per capita, and between credit availability and GNI per capita. The nature of the correlation suggests that the accumulation of financial resources in the banking sector (domestic credit to private sector) and their transformation into credit to the private sector (credit availability) are more significant for low-income and upper-middle-income countries and, consequently, act as a catalyst for the transition to the next income group.

From the point of view of the state economic policy, regulators can directly influence the credit availability (by control of cash settlements, establishment of reserve requirements for commercial banks). In contrast, regulators have an indirect influence on the level of domestic credit to the private sector. Hence, the growth of factors such as the confidence level in the banking system, its reliability, and a decrease in NPL can positively impact a country's lending. Improving the efficiency of the credit mechanism in the economy and increasing the stability of the banking system will stimulate the spread use of credit opportunities, contributing to economic growth and welfare.

Comparison of financial deepening with income group transition status shows that financial depth, on average, is growing in countries with a change in transition. The latter result supports the hypothesis that financial depth reflects a country's economic transformation development trajectory. Countries wishing to jump from a low to a higher group should promote financial deepening. At the same time, an increase in financialization does not mean qualitative financial development. The fast pace of financial deepening will contribute to economic development only to a certain level.

\section{AUTHOR CONTRIBUTIONS}

Conceptualization: Yuliia Shapoval.

Data curation: Oleksii Shpanel-Yukhta.

Formal analysis: Yuliia Shapoval.

Investigation: Yuliia Shapoval.

Methodology: Oleksii Shpanel-Yukhta.

Project administration: Yuliia Shapoval.

Resources: Oleksii Shpanel-Yukhta.

Software: Oleksii Shpanel-Yukhta.

Supervision: Yuliia Shapoval.

Visualization: Oleksii Shpanel-Yukhta.

Writing - original draft: Yuliia Shapoval, Oleksii Shpanel-Yukhta.

Writing - reviewing \& editing: Yuliia Shapoval.

\section{ACKNOWLEDGMENT}

The paper was funded as a part of the "Relationship between financial depth and economic growth in Ukraine" research project (No. 0121U110766), conducted at the State Institution "Institute for Economics and Forecasting of the NAS of Ukraine".

\section{REFERENCES}

1. Abbas, S. M. A., \& Christensen, J. E. (2009). The Role of Domestic Debt Markets in Economic Growth: An Empirical Investigation for Low-Income Countries and Emerging Markets. IMF Staff
Papers, 57(1), 209-255. https://doi. org/10.1057/imfsp.2009.24

2. Anufriieva, K., Brus, S., Bublyk, Y., \& Shapoval, Y. (2021). Ukrainian financial system development: The path to EU. Ikonomicheski Izsled- vania, 30(3), 39-55. Retrieved from https://www.ceeol.com/ search/article-detail?id=942834

3. Arcand, J. L., Berkes, E., \& Panizza, U. (2015). Too much finance? Journal of Economic Growth, 20(2), 
105-148. https://doi.org/10.1007/ s10887-015-9115-2

4. Barthalon, E. (2021). Show me the money: debunking a couple of myths about excess liquidity. Euler Hermes. Retrieved from https:// www.eulerhermes.com/en_global/ news-insights/economic-insights/ Show-me-the-money-debunkinga-couple-of-myths-about-excessliquidity.html

5. Beck, T. (2003). Stock markets, banks, and Economic development: Theory and Evidence. EIB papers, 8(1), 37-54. Retrieved from https://www.econstor.eu/bitstream/10419/44824/1/367786362. pdf

6. Bogdan, T., \& Lomakovych, V. (2021). Financialization of the global economy: macroeconomic implications and policy challenges for Ukraine. Investment Management and Financial Innovations, 18(1), 151-164. http://dx.doi. org/10.21511/imfi.18(1).2021.13

7. Bortz, P. G., \& Kaltenbrunner, A. (2017). The International Dimension of Financialization in Developing and Emerging Economies. Development and Change, 49(2), 375-393. https://doi.org/10.1111/ dech. 12371

8. Brei, M., Ferri, G., \& Gambacorta, L. (2018). Financial structure and income inequality (BIS Working Papers No. 756). Retrieved from https://www.bis.org/publ/work756. pdf

9. Bui, T. N., \& Doan, T. T. T. (2021). The impact of stock market development on economic growth: A GMM approach. Investment Management and Financial Innovations, 18(3), 74-81. https://doi. org/10.21511/imfi.18(3).2021.07

10. Buryk, Z., Bashtannyk, V., \& Ragimov, F. (2019). Economic growth: macroeconomic effects of Public Borrowings at the global level. Problems and Perspectives in Management, 17(3), 169. http://dx.doi. org/10.21511/ppm.17(3).2019.14

11. Chu, C., \& Jiang, M. (2021). Financial depth, income inequality, and economic transition. Southern Economic Journal, 88(1), 199-244. https:/doi.org/10.1002/soej.12523
12. Claessens, S., \& Perotti, E. (2007). Finance and inequality: Channels and evidence. Journal of Comparative Economics, 35(4), 748-773. https://doi.org/10.1016/j. jce.2007.07.002

13. Clarke, G. R., Zou, H. F., \& Xu, L. C. (2003). Finance and income inequality: test of alternative theories (World Bank Working Paper No. 2984). Retrieved from https://documents1.worldbank.org/curated/ en/892521468762914086/pdf/multi0page.pdf

14. Cole, D. C. (1974). Review of Financial Deepening in Economic Development, by E. S. Shaw. The Journal of Finance, 29(4), 1345-1348. https://doi.org/10.2307/2978421

15. Dabla-Norris, M. E., Guo, M. S., Haksar, M. V., Kim, M., Kochhar, M. K., Wiseman, K., \& Zdzienicka, A. (2015). The new normal: A sector-level perspective on productivity trends in advanced economies (IMF Staff Discussion Note No. SDN15/03). https://doi. org/10.5089/9781498334181.006

16. De Haan, J., Pleninger, R., \& Sturm, J.-E. (2021). Does Financial Development Reduce the Poverty Gap? Social Indicators Research. https:// doi.org/10.1007/s11205-021-02705-

17. De Vita, G., \& Luo, Y. (2020). Financialization, household debt and income inequality: Empirical evidence. International Journal of Finance \& Economics, 26(2), 1917-1937. https://doi.org/10.1002/ ijfe. 1886

18. Demetriades, P. O., Rousseau, P. L., \& Rewilak, J. (2017). Finance, Growth and Fragility (University of Leicester Working Papers No. 17/13). Retrieved from https:// www.le.ac.uk/economics/research/ RePEc/lec/leecon/dp17-13.pdf

19. Epstein, G. A. (2005). Financialization and the world economy. Edward Elgar Publishing.

20. Ferreira, C. (2021). Panel Granger causality between financial development and economic growth (REM Working Papers No. 0179-2021). Retrieved from https://rem. rc.iseg.ulisboa.pt/wps/pdf/REM_ WP_0179_2021.pdf
21. Ganguly, S. (2021). Financialization of the Real Economy: New Empirical Evidence from the Non-financial Firms in India Using Conditional Logistic Model. Journal of Quantitative Economics, 19(3), 493-523. https://doi.org/10.1007/s40953-02100242-2

22. Gopinath, G. (2021). A Hobbled Recovery Along Entrenched Fault Lines. IMF blog. Retrieved from https://blogs.imf.org/2021/10/12/ahobbled-recovery-along-entrenched-fault-lines

23. Greenwood, J., \& Jovanovic, B. (1990). Financial Development, Growth, and the Distribution of Income. Journal of Political Economy, 98(5), 1076-1107. https:// doi.org/10.1086/261720

24. Greenwood, J., Sanchez, J. M., \& Wang, C. (2013). Quantifying the impact of financial development on economic development. Review of Economic Dynamics, 16(1), 194-215. https://doi.org/10.1016/j. red.2012.07.003

25. Honohan, P. (2004). Financial development, growth and poverty: how close is the link? (World Bank Working Paper No. 3203). Retrieved from https://www.findevgateway. org/sites/default/files/publications/ files/mfg-en-paper-financial-development-growth-and-poverty-howclose-are-the-links-2004.pdf

26. Index of Economic Freedom. (2021). The Heritage Foundation. Retrieved from https://www.heritage.org/ index

27. International monetary fund (IMF). (2021). International Financial Statistics. Retrieved from https://data. imf.org/?sk=4c514d48-b6ba-49ed8ab9-52b0c1a0179b

28. Kose, M. A., Ohnsorge, F., Reinhart, C., \& Rogoff, K. (2021). Developing economy debt after the pandemic. VoxEU \& CEPR. Retrieved from https://voxeu.org/article/developing-economy-debt-after-pandemic

29. Kotarski, K. (2015). Financial deepening and income inequality: Is there any financial Kuznets curve in China? The political economy analysis. China Economic Journal, 8(1), 18-39. https://doi.org /10.1080/17538963.2015.1001051 
30. Kozmenko, S., \& Korneyev, M. (2017). Formalization of the impact of imbalances in the movement of financial resources on economic growth of countries in Central and Eastern Europe. Accounting and Financial Control, 1(1), 48-58. https://doi. org/10.21511/afc.01(1).2017.06

31. Krippner, G. R. (2005). The financialization of the American economy. Socio-Economic Review, 3(2), 173-208. https://doi. org/10.1093/ser/mwi008

32. Kuznets, S. (1955). Economic Growth and Income Inequality. The American Economic Review, 45(1), 1-28. Retrieved from http:// www.jstor.org/stable/1811581

33. Mader, P., Mertens, D., \& Van der Zwan, N. (Eds.). (2020). The Routledge international handbook of financialization. Routledge.

34. Palley, T. I. (2013). Financialization: What It Is and Why It Matters. Financialization (pp. 17-40).
Palgrave Macmillan. https://doi. org/10.1057/9781137265821_2

35. Panizza, U. (2017). Nonlinearities in the Relationship Between Finance and Growth. Comparative Economic Studies, 60(1), 44-53. https://doi.org/10.1057/s41294017-0043-3

36. Perillo, C., \& Battiston, S. (2020). Financialization and unconventional monetary policy: a financial-network analysis. Journal of Evolutionary Economics, 30(5), 1385-1428. https://doi. org/10.1007/s00191-020-00698-0

37. Rostow, W. W. (1974). Money and Capital in Economic Development. American Political Science Review, 68(4), 1822-1824. https:// doi.org/10.2307/1960040

38. Rushchyshyn, N., Mulska, O., Nikolchuk, Y., Rushchyshyn, M., \& Vasyltsiv, T. (2021). The impact of banking sector development on economic growth: Comparative analysis of Ukraine and some EU countries. Investment Management and Financial Innovations, 18(2), 193-208. https://doi.org/10.21511/ imfi.18(2).2021.16

39. Shkolnyk, I., Kozmenko, S., Kozmenko, O., \& Mershchii, O. (2019). The impact of the economy financialization on the level of economic development of the associate EU member states. Economics and Sociology, 12(4), 43-58. https://doi.org/10.14254/2071789X.2019/12-4/2

40. Shvets, S. (2021). How excessive endogenous money supply can contribute to global financial crises. Banks and Bank Systems, 16(3), 23-33. https://doi. org/10.21511/bbs.16(3).2021.03

41. The World Bank. (2021). World Bank Open Data. Retrieved from https://data.worldbank.org/

42. Thornton, J. (1994). Financial deepening and economic growth: evidence from Asian economies. Savings and Development, 18(1), 41-51. Retrieved from http://www. jstor.org/stable/25830365 